\title{
FEMINISATION OF NAMES OF PROFESSIONS, FUNCTIONS, DEGREES OR TITLES IN THE FRENCH PRESS
}

\author{
Alina Iftime \\ Lecturer PhD., Faculty of Psychology and Educational Sciences, Ovidius University of Constanta, \\ ROMANIA, alinaiftime@yahoo.com
}

\begin{abstract}
Feminisation of names of professions is a set of linguistic processes consisting of explicating women's presence on the public stage.

In this study, we refer to feminisation of terminology or creation of terms denoting feminine professions, titles, degrees and functions, without taking into account texts' feminisation.

In French, female human beings are designated by feminine grammar pronouns, leading to male-female opposition representation with respect to the division of the sexes.

For the feminisation defenders, this representation has considerable social consequences. In French, the masculine gender can be used as generic gender (un professeur may nominate a man or a woman) and it is the gender of a group composed of individuals of both sexes. However, this use was perceived by feminisation upholders as concealing the role of women in public life, and it may even cause psychological strength to stand in certain positions. Therefore, the discussion on the gender of the words denoting status or professional activities of human beings is not only a formal grammar issue, but a matter of sociolinguistics, closely linked to the image that society makes on the relationship between genders and it may even influence these relationships.

In the French current use, it appears that certain feminine professions nouns are used when the job is occupied by a woman, while at some point in the past, when it was not accepted as a woman to occupy that post, the same feminine form was denoting the wife of the man occupying the post.

But French Academy considers that feminisation can introduce an imbalance in the language structures and cause confusion in formulating simple sentences. Although nouns such as professeure, recteure, sapeusepompière, auteure, ingénieure, procureure are considered by the French Academy elected members as „barbarisms", a number of nouns was introduced in the 8th issue of the Dictionary of the Academy: artisane, aviatrice, avocate, bûcheronne, compositrice, éditrice, exploratrice, factrice, pharmacienne, postière.

In this article, based on a corpus of nouns in French written press in the period of September 2016, we will present the evolution of the feminisation of names of professions, highlighting areas in which nouns become easier used in their feminine form. We will examine the position of the press, knowing that the media has a great influence on language changes, while reflecting the mentality of the people.
\end{abstract}

Keywords: French, sociolinguistics, feminisation, names of profession, French press. 


\section{INTRODUCTION}

Any language is dynamic and it is in constant evolution and it adapts to society and to changes over time, linguistic creativity being a sign of the vitality of the language. The words appear either due to the emergence of new things, either because of technical development, or because they acquire a new meaning, or because of social situation such as the feminisation of names of professions, titles, degrees and functions that arose because of a wish of gender equality, first expressed by some feminist groups and then by the state itself.

The process of feminisation of names of professions, functions, degrees or titles, we are witnessing now in France, a political and sociolinguistic process, is not new for the French language, but it started in the 70s in Canada, at the initiative of a feminist movement that proposed the establishment of parity between men and women in the workplace.

Throughout history, man was responsible of the subsistence of the family, by having a profession, he owning the highest social positions. But today, women have access to functions that once belonged to men, and therefore problems related to gender equality appear when it comes to designate by a masculine noun, the position held by a woman, the reason being the lack of an equivalent word to feminine.

The aim of our work is to study whether the language followed the cultural changes, having been based on a corpus of texts from the online press in France. Our intention is to see whether in the colloquially language, feminine forms are being used when there is about a woman.

\section{RESEARCH METHODOLOGY}

The corpus consists of texts extracted from three newspapers, French national newspapers: Le Monde, Le Figaro, L'Humanité. In this corpus, we examine the position of the press, about the feminisation process, given the fact that the media has a great influence on the changes in the language, but also on people's mentality, reflecting at the same time, the attitudes of citizens and the political trends.

Presentation of the selected newspapers: Le Monde is a newspaper founded in 1944 in Paris, historically its articles have politically liberal leftist trend.

Le Figaro, published for the first time in 1826, is a conservative right-wing newspaper, posing in its articles economic and social problems. Le Figaro and Le Monde, are among the most important informative newspapers in France.

L'Humanité is the former newspaper of the French Communist Party (PCF), founded in 1904 by Jean Jaurès. Currently, the newspaper is independent but it maintains some ties to the Communist Party.

We intend to examine in these three newspapers, the attitude towards feminisation of names of professions, more specifically, to identify, if any, differences in terms of feminization, knowing that before "the debate on the feminisation" which has grown in 80s, some conservative newspapers have resisted to evolution of gender equality. The reason we chose these publications is that they have existed for over 50 years, which indicates that there are not some ephemeral actors in the media world, and, moreover, they are disseminated widely, including online.

For this study, we collected articles from the three mentioned newspapers inserting into the search engine on the website of each newspaper, a form of feminine noun denoting a profession, as provided by the feminization guides in France, but also by the French Academy. We searched automatically in the database of the newspapers, the co-occurrence of nouns taken from the indicative list of the guide Femme, j'écris ton nom: Guide d'aide à la féminisation des noms de métiers, titres, grades, fonctions, nouns among which we noted differences from the noun imposed by the French Academy.

\section{HYPOTHESIS}

The hypothesis of this study was that there is some link between gender parity, on the one hand, and the amount and frequency of the feminine nouns, on the other hand.

\section{RESULTS}

\subsection{Ranking and analysing of the corpus of names of professions}

We studied the articles which referred to a profession in itself, not only to an individual who practiced that profession. Of these nouns naming professions, a small number refers to a woman (according to the gender of the noun (celui de la meilleure actrice), the rest refers to a man or we identified the collective and generic value of the masculine, meaning cases where generally it is speaking either about jobs or workers (le 
sacerdoce des professeurs stagiaires) or positions or functions (le poste de rédacteur en chef, le mandat de maire, les fonctions d'enseignant-chercheur).

We must not overlook that, under those names that refer to a man, there are women too, but from the need of a neutral, it is simple to use the generic masculine, because it considerably makes easier the reading of a text and, moreover, in French, the plural is given to masculine. We chose to identify only the masculine names appeared in the singular, referring to a concrete person, to avoid misunderstanding that might occur for plural.

To illustrate the occurrence of different names of professions in the articles, we present the table below, table 1 , where we insert the masculine noun and its number of appearances in the newspaper articles, and its feminine equivalent, according to the indicative list of Becquer A. et al. (Becquer, A., Cerquiglini, B. et al. 1999. Indicative list of feminine nouns: 58-118) and its occurrences.

Table 1. Data that relate to names of professions, functions, grades or titles that refer to a person in the newspapers Le Monde, Le Figaro, L'Humanité, inventoried on September 2016.

\begin{tabular}{|c|c|c|c|c|c|}
\hline $\begin{array}{l}\text { Nr. } \\
\text { crt. }\end{array}$ & $\begin{array}{l}\text { The masculine } \\
\text { form }\end{array}$ & $\begin{array}{l}\text { The number of } \\
\text { occurrences in } \\
\text { the articles } \\
\text { studied }\end{array}$ & The feminine form & $\begin{array}{l}\text { The number of } \\
\text { occurrences in } \\
\text { the articles } \\
\text { studied }\end{array}$ & $\begin{array}{l}\text { The French Academy } \\
\text { Dictionary form }\end{array}$ \\
\hline 1 & l'acteur & 131 & l'actrice & 44 & l'actrice \\
\hline 2 & l'ambassadeur & 47 & l'ambassadrice & 17 & l'ambassadeur - m. \\
\hline 3 & l'assureur & 10 & l'assureuse & 0 & l'assureur - m. \\
\hline 4 & l'auteur & 312 & $\begin{array}{l}\text { l'auteur(e) } \\
\text { The forms auteuse, } \\
\text { autrice, aut(h)oresse } \\
\text { - are certified, but } \\
\text { rarely used }\end{array}$ & 47 & l'auteur - m. \\
\hline 5 & l'avocat & 171 & l'avocate & 24 & l'avocate \\
\hline 6 & le batteur & 8 & la batteuse & 0 & le batteur $-\mathrm{m}$. \\
\hline 7 & le bottier & 1 & la bottière & 0 & le bottier - m. \\
\hline 8 & le boucher & 9 & la bouchère & 0 & $\begin{array}{l}\text { le boucher }-m \text {. } \\
\text { la bouchère }-f .- \\
\text { designates the wife or } \\
\text { the woman having a } \\
\text { butcher affair. }\end{array}$ \\
\hline 9 & le capitaine & 63 & la capitaine & 2 & le capitaine $-\mathrm{m}$ \\
\hline 10 & le chauffeur & 42 & la chauffeuse & 0 & $\begin{array}{l}\text { le chauffeur }-\mathrm{m} \text {. } \\
\text { la chauffeuse - chair to } \\
\text { sit down by the fire }\end{array}$ \\
\hline 11 & le chef & 718 & la cheffe & 10 & le chef $-\mathrm{m}$ \\
\hline 12 & le chercheur & 118 & $\begin{array}{l}\text { la chercheuse } \\
\text { la chercheure }\end{array}$ & $\begin{array}{l}28 \\
0\end{array}$ & la chercheuse \\
\hline 13 & le chirurgien & 12 & la chirurgienne & 0 & le chirurgien $-\mathrm{m}$. \\
\hline 14 & le commandant & 44 & la commandante & 1 & le commandant $-\mathrm{m}$. \\
\hline 15 & le conseiller & 19 & la conseillère & 1 & la conseillère \\
\hline 16 & le consul & 6 & la consule & 1 & le consul - m. \\
\hline 17 & le couturier & 11 & la couturière & 3 & le couturier - m. \\
\hline 18 & le directeur & 591 & la directrice & 156 & la directrice \\
\hline 19 & l'écrivain & 128 & l'écrivaine & 22 & l'écrivain - m. \\
\hline 20 & l'enquêteur & 13 & $\begin{array}{l}\text { l'enquêteuse } \\
\text { l'enquêtrice }\end{array}$ & $\begin{array}{l}0 \\
1\end{array}$ & l'enquêteuse \\
\hline 21 & l'expert & 68 & l'experte & 0 & l'expert - m. \\
\hline 22 & le gendarme & 16 & une grendarme & 0 & le gendarme $-\mathrm{m}$. \\
\hline 23 & le gouverneur & 65 & $\begin{array}{l}\text { la gouverneur } \\
\text { la gouverneure }\end{array}$ & $\begin{array}{l}1 \\
1\end{array}$ & le gouverneur - m. \\
\hline 24 & l'imprimeur & 6 & l'imprimeuse & 0 & l'imprimeur - m. \\
\hline 25 & l'ingénieur & 44 & l'ingénieure & 0 & $\begin{array}{l}\text { l'ingénieur - m. } \\
\text { une femme ingénieur }\end{array}$ \\
\hline 26 & le lieutenant & 8 & la lieutenante & 1 & le lieutenant $-\mathrm{m}$. \\
\hline 27 & le magistrat & 23 & la magistrate & 6 & le magistrat $-\mathrm{m}$. \\
\hline 28 & $\begin{array}{l}\text { le manager } \\
\text { le manageur }\end{array}$ & $\begin{array}{l}25 \\
15 \\
\end{array}$ & la manageuse & 0 & $\begin{array}{l}\text { le manager / le } \\
\text { manageur }-\mathrm{m} \text {. }\end{array}$ \\
\hline 29 & le marin & 6 & $\begin{array}{l}\text { la marine } \\
\text { femme marin }\end{array}$ & $\begin{array}{l}0 \\
1\end{array}$ & le marin - m. \\
\hline
\end{tabular}


IJASOS- International E-Journal of Advances in Social Sciences, Vol. III, Issue 7, April 2017

\begin{tabular}{|c|c|c|c|c|c|}
\hline 30 & le médecin & 102 & médecin(e) & 0 & $\begin{array}{l}\text { le médecin - m. } \\
\text { une femme médécin }\end{array}$ \\
\hline 31 & le menuisier & 1 & la menuisière & 0 & le menuisier - m. \\
\hline 32 & l'officier & 28 & l'officière & 0 & l'officier - m. \\
\hline 33 & le patron & 244 & la patronne & 0 & $\begin{array}{l}\text { la patronne } \\
\text { une femme patron }\end{array}$ \\
\hline 34 & le peintre & 14 & la peintre & 0 & $\begin{array}{l}\text { le peintre }-\mathrm{m} . \\
\text { une femme peintre }\end{array}$ \\
\hline 35 & le pilote & 71 & la pilote & 0 & le pilote $-\mathrm{m}$ \\
\hline 36 & le plombier & 4 & la plombière & 0 & le plombier $-\mathrm{m}$. \\
\hline 37 & le poète & 39 & $\begin{array}{l}\text { le poète } \\
\text { la poétesse }\end{array}$ & $\begin{array}{l}1 \\
4 \\
\end{array}$ & le poète $-\mathrm{m}$. \\
\hline 38 & le prefet & 49 & la préfète & 3 & le prefet $-\mathrm{m}$. \\
\hline 39 & le procureur & 97 & $\begin{array}{l}\text { la procureure } \\
\text { la procureuse }\end{array}$ & $\begin{array}{l}10 \\
0\end{array}$ & le procureur - m. \\
\hline 40 & le professeur & 206 & $\begin{array}{l}\text { la professeure } \\
\text { une professeur }\end{array}$ & $\begin{array}{l}26 \\
1\end{array}$ & le professeur $-\mathrm{m}$ \\
\hline 41 & le proviseur & 3 & la proviseure & 0 & le proviseur - m. \\
\hline 42 & le régisseur & 1 & la régisseuse & 0 & $\begin{array}{l}\text { le régisseur }-\mathrm{m} \text {. } \\
\text { - the feminine form } \\
\text { denominates his wife }\end{array}$ \\
\hline
\end{tabular}

The following nouns occur only in masculine: l'assureur, le batteur, le bottier, le boucher, le chauffeur, le chirurgien, l'expert, le gendarme, l'imprimeur, l'ingénieur, le manager / le manageur, le médecin, le menuisier, l'officier, le patron, le peintre, le pilote, le plombier, le proviseur, le régisseur, le reporter. For these nouns, we have not found feminine occurrences, but we believe that the reason for this is simply hazard.

As noted in the table, nouns of professions that occur most frequently in articles (le / la chef, le directeur / la directrice) represent a high position. Among them, the masculine forms constitute the vast majority, which means that men are better represented than women in their profession.

Among the examined nouns, we found three interesting cases: the varied forms of feminine une gouverneur / la gouverneur, une poète / la poétesse, une professeur / la prefesseure. They occur either in the epicene form or by adding an -e at to the end. According to the indicative list, these two forms are possible.

\subsection{Compliance with the recommendations of feminization rules}

In this part of the paper we summarize as visible as feminization of names of professions, functions, grades or titles is in written current French used by the press. After 1999, when the indicative list has been provided, in theory, there was no ambiguity in denominating women professionally, but as we noted, in practice there are still obstacles. We noticed that there are still more men than women in senior posts, making the need to secure the feminine form in certain professional fields to be quite weak. But perhaps the more there will be more women in these positions, the pressure will become stronger for feminization.

After analyzing the corpus, we can conclude that the newspapers respect the given recommendations of feminization, according to the sex of the concerned person, we can capture the clear trends of the process of feminization.

An obstacle rather social and historical than linguistic is that the feminine is derogatory in a hierarchy. For example, a director is often considered a head of a high position, but the first impression for une directrice is a person who runs a school, but this image is increasingly less present. Among the directors in the articles we found a director of an association, a marketing executive, a weekly newspaper director, a director of the health department, an Executive Director etc. On the labour market, no one wants to be considered in an inferior position than the reality because it is about authority and respect.

We found aut there are no differences in the compliance of the rules of feminization in the three newspapers that have provided us the corpus. The feminine has been well used regarding the women exercising a profession, but overall masculine predominance makes women become invisible, which could be a factor that hampers the linguistic feminization.

Although in France, there are strong opinions for the linguistic conservatism, expressed in particular by the French Academy, it is obvious that women are increasingly present in all areas of the society, so that the official media, but also the women must decide which would be the best practice in the future. We make this remark because there are women who, being called in a post, they want to be officially called by the masculine noun, for example Madame l'Ambassadeur. We notice the actuality of Albert Dauzat's remark "the woman who prefers to her name profession the masculine form, accuses actually an inferiority complex that 
contradicts her legitimate claims." (Dauzat A., Le Guide du bon usage 1955; quoted by Becquer, A., Cerquiglini, B. et al. 1999: 33)

Regarding languages with genres such as French language, we must reflect on the nature of the grammatical gender system. We noticed, in the French press that, the visible masculine form with a determinant or a masculine adjective, tends to be avoided, even for nouns whose feminization is not yet widespread. The complete feminisation of names of professions, functions, grades or titles, would be a way for the French language to turn into a non-sexist language, if possible. French language could become the language where the grammatical gender corresponds precisely to the sex of the referent. But even if it were used for all the professions feminine nouns, the inegalitarian aspects still would not disappear as there would exist the "generic" masculine, used to describe only the position but also the masculine plural designating a group of men and women. So, it is practically impossible to lose all traces of inequality in French, which raises questions about the limits of feminization.

\section{CONCLUSION}

The objective of our study was to see if the language followed the cultural changes and to notice which the current trends are. So it seems the rules to feminize were relatively easy to create, but the feminization arise however some difficulties, because of the history and the semantic blockages we find in French. These barriers may disappear with time passing in everyday use, but it seems the French Academy will remain in position against this development.

One of the questions posed at the beginning of the study it was whether feminization is actually used routinely in the press today, and whether it has become the norm or there is still resistance against the feminisation. From the results obtained from our analysis, we see that women titles are frequently used in the publications that constitute our corpus. Even if there is a resistance against the feminisation of names of professions, and whether the feminization of names and positions of prestige is not complete, we can conclude that the application of feminine names in the press today is actually the norm in France.

Hypothesis and the starting point of this work was that there is some link between gender parity in society, on the one hand and the amount and frequency of the feminine names, on the other hand. After analysing the information found during the investigation, it makes us believe that gender parity is not very important in France and that is why there is a need to strengthen the gender equality through language, by using feminine forms.

\section{REFERENCE LIST}

Dictionnaire de l'Académie française, neuvième édition, version informatisée. http://atilf.atilf.fr/dendien/scripts/generic/cherche.exe?15;s=1654505280;;

Becquer, A. et all. (1999). Femme, j'écris ton nom ... Guide d'aide à la féminisation des noms de métiers, titres, grades et fonctions. Préface de Lionel Jospin. Paris: CNRS-InaLF. 124 p. http://www.culture.gouv.fr/culture/dglf/ressources/feminisation.pdf

Dauzat A., Le Guide du bon usage 1955 ; quoted by Becquer, A. et all. (1999). Femme, j'écris ton nom ... Guide d'aide à la féminisation des noms de métiers, titres, grades et fonctions. Préface de Lionel Jospin. Paris: CNRS-InaLF. 124 p.: 33

http://www.lemonde.fr/ [visited on September 2016]

http://lefigaro.fr/ [visited on September 2016]

http://www.humanite.fr/ [visited on September 2016] 